\title{
Changes in composition, diversity and structure of woody plants in successional stages of tropical dry forest in southwest Mexico
}

\section{Cambios en la composición, diversidad y estructura de plantas leñosas en estados sucesionales de bosque tropical seco en el suroeste de México}

\author{
R. Carlos Almazán-Núñez ${ }^{1}$, María del Coro Arizmendi², Luis E. Eguiarte ${ }^{3}$ and Pablo Corcuera ${ }^{4 凶}$ \\ ${ }^{I}$ Doctorado en Ciencias Biológicas y de la Salud, Universidad Autónoma Metropolitana-Iztapalapa. Av. San Rafael Atlixco 186. Col. Vicentina \\ Iztapalapa, 09340 México, D. F., México. \\ ${ }^{2}$ Laboratorio de Ecología, Unidad de Biotecnología y Prototipos, Facultad de Estudios Superiores Iztacala, Universidad Nacional Autónoma de \\ México. Av. De los Barrios 1, Los Reyes de Iztacala, 54090 Tlalnepantla, Estado de México, México. \\ ${ }^{3}$ Departamento de Ecología Evolutiva, Instituto de Ecología, Universidad Nacional Autónoma de México. Apartado postal 70-399. Circuito exterior, \\ Ciudad Universitaria, 04510 México, D. F. México. \\ ${ }^{4}$ Departamento de Biología, Universidad Autónoma Metropolitana-Iztapalapa. Av. San Rafael Atlixco 186. Col. Vicentina Iztapalapa, 09340 México, \\ D. F., México. \\ \pcmr@xanum.uam.mx
}

\begin{abstract}
We analyzed the changes in composition, diversity and structure of trees and shrubs along a successional gradient in southwest Mexico. Early stages were dominated by typical pioneer species but species of mature forests were present throughout the chronosequence, and therefore the species plant distribution between stages may be explained by the initial floristic composition model. Because sites from all stages had similar number of species, our study does not support the intermediate levels of disturbance hypothesis. Contrary to the patterns observed in other dry forests, the mature stages presented a relatively simple structure complexity compared to that of intermediate forests. This resulted from a few dominant species which are usually present in mature forests with some degree of perturbation. According to the polyclimax hypothesis, diversity of the mature forests appears to be influenced by local soil conditions, microclimates and biotic factors. Our study supports this idea because local conditions vary between sites and the dominant species of the late stages were different between stands. The conservation and management plans should be directed to different successional stages and not only to single patches in order to ensure the conservation of regional biodiversity.
\end{abstract}

Key words: Bursera, conservation, dominance, abiotic factors, secondary succession.

Resumen. Se analizó la composición, diversidad y estructura de los árboles y arbustos en un un gradiente sucesional en el suroeste de México. Las etapas tempranas presentaron mayor dominancia de especies típicas pioneras, pero especies de bosques maduros se encontraron en todos los sitios, tal como predice el modelo de la composición florística inicial. Debido a que todos los sitios tuvieron una riqueza similar, nuestro estudio no apoya la hipótesis de la perturbación intermedia. Contrario a los patrones observados en otros bosques secos, la estructura de la vegetación resultó menos compleja en las etapas maduras en comparación con las intermedias. Esto es resultado de especies dominantes que se encuentran en bosques maduros con algún grado de perturbación. De acuerdo con la teoría del policlímax, la diversidad en bosques maduros es resultado del microclima, condiciones edáficas y factores bióticos. Nuestros resultados apoyan esta idea ya que las condiciones locales varían entre sitios y las especies dominantes de las etapas tardías fueron diferentes entre los sitios. Los esfuerzos para la conservación de áreas, así como los planes de manejo deben contemplar diferentes etapas sucesionales y no sólo parches aislados, con el fin de asegurar la conservación de la biodiversidad regional.

Palabras clave: Bursera, conservación, dominancia, factores abióticos, sucesión secundaria.

\section{Introduction}

Ecological succession refers to the chronological changes in the structure, taxonomic composition and

Recibido: 24 febrero 2012; aceptado: 25 junio 2012 function of an ecosystem after a disturbance (Kayes et al., 2010; Prach and Walker, 2011). This phenomenon was initially conceived as a natural process of ecological communities (Connell and Slatyer, 1977). However, anthropogenic disturbances which induce changes in nutrient composition and plant communities are now the 
leading causes, which shape the vegetation development (Walker et al., 2010).

The secondary succession dynamics depends largely on the nature of the disturbance (extent, intensity, frequency), abiotic conditions prevailing in the disturbed site, such as local climate and soil conditions (sensu Tansley, 1935), the availability of regenerative propagules (seeds, local native seedlings) and biotic factors (e.g., predators, granivores, frugivores, parasites) (Álvarez-Yépiz et al., 2006; Davies and Semui, 2006; Chazdon, 2008). In this sense, communities with different plant composition can represent distinct mature stages in the same geographical area. In addition, the non-equilibrium hypothesis first proposed by Grime (1973) and formalized by Connell (1978), suggests that species richness should be higher at intermediate levels of disturbance (ILD hypothesis). Under these circumstances conditions are not so adverse as to eliminate species but are unfavorable enough to check population densities and thus avoid the displacement of species by competition.

However, this hypothesis has been challenged as too simplistic because it only makes qualitative predictions about changes in species diversity in response to disturbance frequency, but does not consider local physical factors such as soil and land relief and other variations associated with the species microhabitats (Collins and Glenn, 1997; McCabe and Gotelli, 2000; Roxburgh et al., 2004). On the other hand, according to the initial floristic composition model (Egler, 1954), species from late stages may also be present in the stands initial successional process (Collins et al., 2005). Accordingly, the composition of mature forest is likely the result of various factors such as the initial suite of species present, seed dispersal, facilitation and competition, longevity, plant-animal interactions and stochastic extinction/colonization processes (sensu Walker and Chapin, 1987; Pickett and McDonnell, 1989), which result in different compositions in forest stands of the same general vegetation type but located in different locations.

Almost all tropical dry forests (TDF) of Mesoamerica, are currently represented by secondary succession fragments (Stoner and Sánchez-Azofeita, 2009; DeClerck et al., 2010; Griscom and Ashton, 2011) due to plant extraction, livestock and agricultural pressures (Quesada and Stoner, 2004). As in other ecosystems, human disturbance has transformed the structural heterogeneity and composition of TDF (Aide et al., 2000; Onaindia et al., 2004; Kayes et al., 2010). When dry forests are not completely transformed to pastures or fields, intermediate level anthropogenic disturbances can result in a higher floristic diversity, biomass and density of woody vegetation than the original mature stages (Chapman and Chapman, 1990; Kalacska et al., 2004; Leirana et al., 2009; Madeira et al., 2009; Powers et al., 2009), as predicted by the ILD hypothesis.

Although some efforts have been made to analyze the successional patterns in TDF, there is very little information in comparison to the number of studies completed in tropical rain forests (Vieira and Scariot, 2006; Quesada et al., 2009). It is known that TDF hosts a high floristic richness in addition to high species endemism levels (Rzedowski, 1978; Gillespie et al., 2000; Trejo and Dirzo, 2002; De-Nova et al., 2012). At present, sensible management and conservation strategies have been less successful in the TDF than in other tropical forests (Sánchez-Azofeita et al., 2005; Vieira and Scariot, 2006). However, their recovery will depend largely on the knowledge of successional chronosequence, which includes composition, diversity and structural changes (Janzen, 1988a).

In this study we compared fragments representing different successional stages to describe changes in species composition and diversity, as well as cover, density and foliage layer complexity of the trees and shrubs with diameter at breast height $(\mathrm{DBH}) \geq 10 \mathrm{~cm}$ within the Balsas basin, in Guerrero, Mexico. Although land use, topography and availability of propagules may differ between fragments and between sites within similar successional stages, we expect to find (i) that differences in environmental and structural attributes of vegetation are determined by the successional stage, and (ii) that plant species richness will be greater in sites represented by intermediate successional stages, as suggested by the ILD hypothesis (Connell, 1978).

\section{Materials and methods}

Study area and sampling sites. The study site, known as La Organera-Xochipala, is located in the Balsas basin biotic province, between $17^{\circ} 47^{\prime} 46.65^{\prime \prime}-17^{\circ} 49^{\prime} 11.14^{\prime \prime} \mathrm{N}$, 99 $35^{\prime} 36.50^{\prime \prime}-99^{\circ} 38^{\prime} 30.46^{\prime \prime} \mathrm{W}$ (Fig. 1). The prevailing climate (according to the Köppen classification) is semiarid (Meza and López, 1997), with an average temperature of $23.9^{\circ} \mathrm{C}$ and $684 \mathrm{~mm}$ of annual precipitation. The rainy season is between June and October (Peralta, 1995).

The study was conducted in 9 fragments represented by different successional stages: $a$ ), 3 disturbed sites (early stage of succession $\approx 20$ years, ES), which consisted of secondary vegetation in places formerly used for ranching and farming; $b$ ), 3 sites representing a transition between early and mature forests (intermediate stage $\approx 35$ years, IS). Although these sites have suffered from different types of disturbance, they still maintain some of the floristic and structural elements of the original vegetation and $c$ ), 3 relatively well preserved sites (mature stage $\geq 50$ years, MS) characterized by the typical structure and cover of 


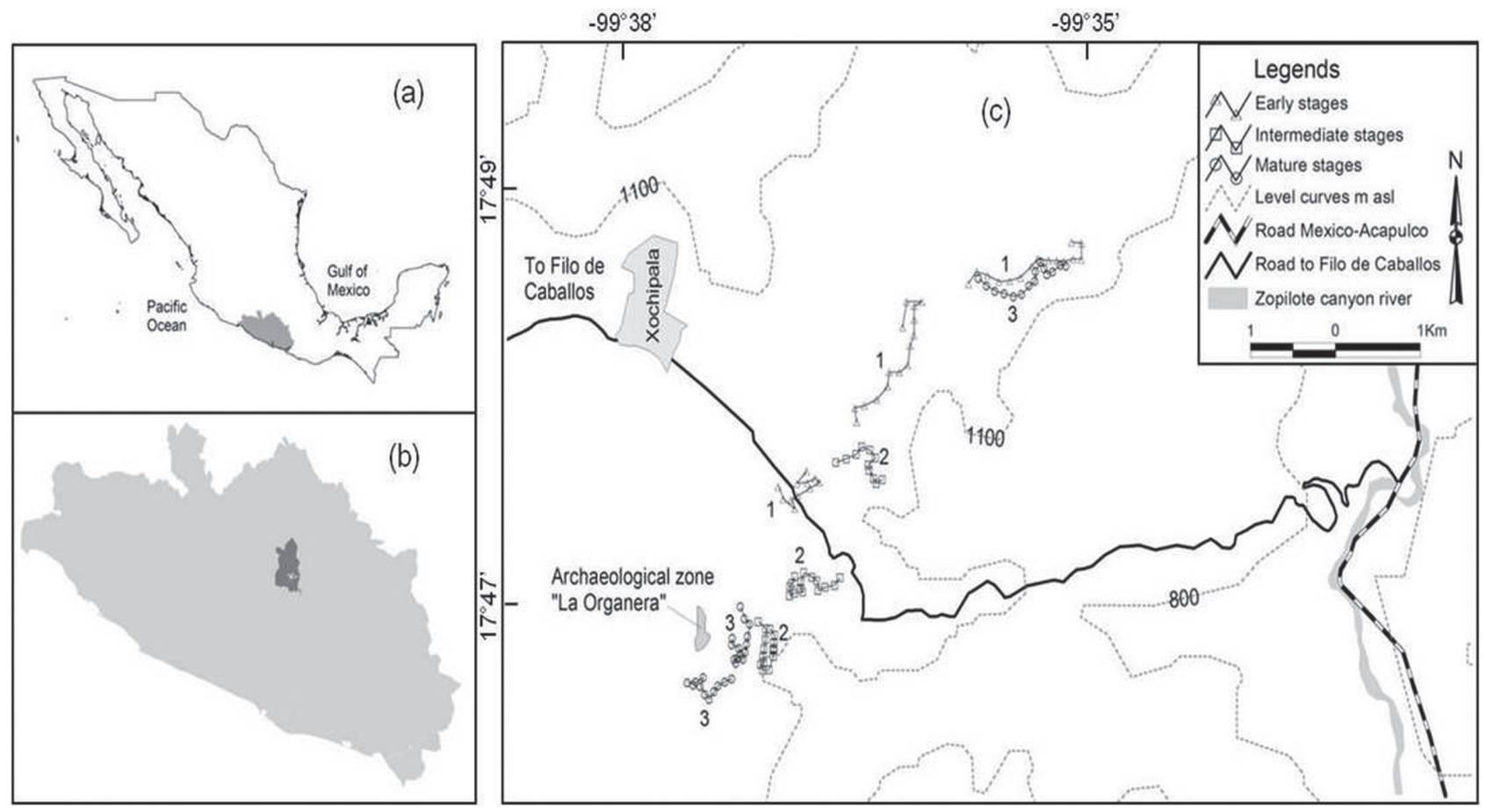

Figure 1. Location of the Mexican state of Guerrero (a), Zopilote Canyon (b) and sampling plots in Organera-Xochipala tropical dry forest. $1=$ early stages, $2=$ intermediate stages, $3=$ mature stages.

mature TDF (e.g., dominance of Bursera sp.). Historically, the sites have been clear cut and burned to open land for cattle ranching and agricultural activities. The secondary vegetation sites in this study were selected based on information about time since last major disturbance (i.e., cutting, clearing and fire) obtained from interviews with farmers.

Sampling of vegetation. For each successional stage, we selected 2 sites with 15 sample plots and 1 with 11 (41 plots per stage). The difference in the number of plots was due to the topography, which made some areas inaccessible. The average distance between plots was $200 \mathrm{~m}$ and the radius was $30 \mathrm{~m}\left(2827.44 \mathrm{~m}^{2}\right.$ or $0.28 \mathrm{ha}$; Fig. 1). In each of the 123 sample 2 perpendicular lines, directed to the four cardinal points, were marked with a rope. All individuals (trees and shrubs $\geq 10 \mathrm{~cm} \mathrm{DBH}$ ) whose branches intersected the rope were identified. The cover for each of these plants was estimated with the ellipse formula using the maximum and minimum diameter lengths (Muller-Dombois and Ellenberg, 1974). Stratification was determined with an optical square marked with 2 perpendicular axes (Montaña and Ezcurra, 1980). The square has 3 mirrors arranged so that a person looking horizontally can see the objects found above the apparatus. In each plot we recorded the height and counted the foliage contacts with the point of intersection 60 times every $50 \mathrm{~cm}$ in 4 transects oriented to the cardinal points. The heights were grouped in one- meter intervals and the foliage height diversity (FHD) was assessed with the Shannon-Wiener index.

The specimens collected were deposited in the Faculty of Science herbarium of the Universidad Nacional Autónoma de México (UNAM). The list of species present in the study area follows the family classification of Stevens (2001) and the genera and species nomenclature according to the database of the Missouri Botanical Garden (W3Tropicos, 2010).

Data analysis. We used the Chao2 estimator to compare richness $(S)$ between sites and successional stages and to assess the comprehensiveness of the composition survey (Colwell and Coddington, 1994). To compare species richness among sites and successional stages, we performed rarefaction analysis for unequal number of individuals in sites. Both analysis were done with EstimateS v. 8.0 (Colwell, 2006). We also counted the number of individuals and used the Shannon-Wiener $\left(H^{\prime}\right)$ and the Pielou indices $(E)$ to assess the species diversity and evenness. The Simpson index $(D)$ was used as a measure of dominance (Brower et al., 1998). The relative importance value (RIV) was based on the frequency, density and dominance of each species (Mueller-Dombois and Ellenberg, 1974).

Non-parametric Kruskall-Wallis tests were used to compare the diversity indices between sites and successional stages because data did not meet the assumptions of 
normality and homogeneity of variances according to the Kolmogorov-Smirnov and Levenne tests. The contrasts were appraised with the Mann-Whitney $U$ test. Plant cover, density and FHD were compared between sites and successional stages with unbalanced two-way ANOVA (factor 1: successional stage, factor 2: sites). A posteriori comparisons were analyzed with the Tukey HSD test using SPSS 17.0 (SPSS, 2008).

The plant community similarities were analyzed with an unweighted pair group average method (UPGMA) with the chord dissimilarity coefficient (Orlóci, 1978). We used this distance because it achieves a better representation of the relationships between objects in comparison with other measures (Legendre and Gallagher, 2001). We also performed a correspondence analysis (CA) in order to inspect the distribution of the plant species between sites and successional stages. The classification was executed with the
MVSP 3.13r multivariate statistical package (Kovach, 2009) and CANOCO (version 4.5) was used for the CAordination (Ter Braak and Smilauer, 2002). The significance of the difference between the classification groups was assessed by means of a discriminant analysis using the Wilks' lambda $(\lambda)$ criterion, which takes values from 0 (when all groups are different) to 1 (when groups do not differ; SPSS, 2008).

\section{Results}

Floristic composition. We found 4620 individuals corresponding to 55 tree and 28 shrub species, 57 genera and 30 families (Table 1). Fabaceae, with 22 species, followed by Burseraceae (13), Euphorbiaceae (5), Rubiaceae (5) and Anacardiaceae (4) represented 59\% of total species recorded. The remaining families had 3 or fewer species (Table 1).

Table 1. Plant species composition (DBH $\geq 10 \mathrm{~cm}$ ) identified in nine sites of 3 successional stages in a tropical dry forest in La Organera-Xochipala, Guerrero, Mexico. ES: early stage, IS: intermediate stage, MS: mature stage

\begin{tabular}{|c|c|c|c|c|c|c|c|c|c|c|c|}
\hline \multirow[t]{2}{*}{ Family } & \multirow[t]{2}{*}{ Species } & \multirow[t]{2}{*}{ Life form } & \multicolumn{3}{|c|}{$E S$} & \multicolumn{3}{|c|}{$I S$} & \multicolumn{3}{|c|}{$M S$} \\
\hline & & & 1 & 2 & 3 & 1 & 2 & 3 & 1 & 2 & 3 \\
\hline \multirow[t]{4}{*}{ Anacardiaceae } & Amphipterygium adstringens & Tree & & & $\mathrm{x}$ & & & & & & \\
\hline & Cyrtocarpa procera & Tree & & & & $\mathrm{x}$ & $\mathrm{x}$ & $\mathrm{x}$ & & $\mathrm{x}$ & $\mathrm{x}$ \\
\hline & Pseudosmodingium andrieuxii & Tree & & $\mathrm{x}$ & $\mathrm{x}$ & $\mathrm{x}$ & $\mathrm{x}$ & $\mathrm{x}$ & & & $\mathrm{x}$ \\
\hline & Pseudosmodingium perniciosum & Tree & & $\mathrm{x}$ & & & $\mathrm{x}$ & $\mathrm{x}$ & & & $\mathrm{x}$ \\
\hline \multirow[t]{3}{*}{ Apocynaceae } & Plumeria rubra & Tree & & & & & $\mathrm{x}$ & $\mathrm{x}$ & & $\mathrm{x}$ & $\mathrm{x}$ \\
\hline & Rauvolfia tetraphylla & Tree & & & & & & & & $\mathrm{x}$ & \\
\hline & Thevetia sp. & Shrub & $\mathrm{x}$ & $\mathrm{x}$ & $\mathrm{x}$ & & $\mathrm{x}$ & & & $\mathrm{x}$ & \\
\hline \multirow[t]{2}{*}{ Bignoniaceae } & Crescentia alata & Tree & $\mathrm{x}$ & & & & & $\mathrm{x}$ & & & \\
\hline & Tecoma stans & Shrub & & & $\mathrm{x}$ & $\mathrm{x}$ & $\mathrm{x}$ & $\mathrm{x}$ & $\mathrm{x}$ & $\mathrm{x}$ & $\mathrm{x}$ \\
\hline \multirow[t]{2}{*}{ Bombacaceae } & Ceiba parvifolia & Tree & $\mathrm{x}$ & $\mathrm{x}$ & $\mathrm{x}$ & $\mathrm{x}$ & $\mathrm{x}$ & $\mathrm{x}$ & $\mathrm{x}$ & & $\mathrm{x}$ \\
\hline & Pseudobombax ellipticum & Tree & & & & & & $\mathrm{x}$ & & $\mathrm{x}$ & \\
\hline \multirow[t]{2}{*}{ Boraginaceae } & Cordia elaeagnoides & Tree & $\mathrm{x}$ & $\mathrm{x}$ & & & & & $\mathrm{x}$ & & \\
\hline & Cordia sp. & Tree & $\mathrm{x}$ & & $\mathrm{x}$ & $\mathrm{x}$ & $\mathrm{x}$ & $\mathrm{x}$ & $\mathrm{x}$ & $\mathrm{x}$ & $\mathrm{x}$ \\
\hline \multirow[t]{9}{*}{ Burseraceae } & Bursera aptera & Tree & $\mathrm{x}$ & & $\mathrm{x}$ & $\mathrm{x}$ & $\mathrm{x}$ & $\mathrm{x}$ & $\mathrm{x}$ & & $\mathrm{x}$ \\
\hline & Bursera chemapodicta & Tree & & & & $\mathrm{x}$ & & $\mathrm{x}$ & & $\mathrm{x}$ & $\mathrm{x}$ \\
\hline & Bursera fagaroides & Tree & $\mathrm{x}$ & $\mathrm{x}$ & $\mathrm{x}$ & $\mathrm{x}$ & $\mathrm{x}$ & $\mathrm{x}$ & $\mathrm{x}$ & $\mathrm{x}$ & $\mathrm{x}$ \\
\hline & Bursera grandifolia & Tree & $\mathrm{x}$ & $\mathrm{x}$ & $\mathrm{x}$ & $\mathrm{x}$ & $\mathrm{x}$ & & & & \\
\hline & Bursera lancifolia & Tree & & & & & & & $\mathrm{x}$ & & \\
\hline & Bursera longipes & Tree & $\mathrm{x}$ & $\mathrm{x}$ & $\mathrm{x}$ & $\mathrm{x}$ & $\mathrm{x}$ & $\mathrm{x}$ & $\mathrm{x}$ & $\mathrm{x}$ & $\mathrm{x}$ \\
\hline & Bursera mirandae & Tree & & $\mathrm{x}$ & $\mathrm{x}$ & $\mathrm{x}$ & $\mathrm{x}$ & $\mathrm{x}$ & $\mathrm{x}$ & $\mathrm{x}$ & \\
\hline & Busera morelensis & Tree & $\mathrm{x}$ & $\mathrm{x}$ & $\mathrm{x}$ & $\mathrm{x}$ & $\mathrm{x}$ & $\mathrm{x}$ & $\mathrm{x}$ & $\mathrm{x}$ & $\mathrm{x}$ \\
\hline & Bursera schlechtendalii & Tree & & & $\mathrm{x}$ & $\mathrm{x}$ & $\mathrm{x}$ & $\mathrm{x}$ & $\mathrm{x}$ & $\mathrm{x}$ & $\mathrm{x}$ \\
\hline
\end{tabular}


Table 1. Continues

\begin{tabular}{|c|c|c|c|c|c|c|c|c|c|c|c|}
\hline \multirow[t]{2}{*}{ Family } & \multirow[t]{2}{*}{ Species } & \multirow[t]{2}{*}{ Life form } & \multicolumn{3}{|c|}{$E S$} & \multicolumn{3}{|c|}{$I S$} & \multicolumn{3}{|c|}{$M S$} \\
\hline & & & 1 & 2 & 3 & 1 & 2 & 3 & 1 & 2 & 3 \\
\hline & Busera submoniliformis & Tree & & $\mathrm{x}$ & & $\mathrm{x}$ & $\mathrm{x}$ & $\mathrm{x}$ & $\mathrm{x}$ & $\mathrm{x}$ & $\mathrm{x}$ \\
\hline & Bursera suntui & Tree & & & $\mathrm{x}$ & $\mathrm{x}$ & $\mathrm{x}$ & $\mathrm{x}$ & $\mathrm{x}$ & $\mathrm{x}$ & $\mathrm{x}$ \\
\hline & Bursera vejarvazquezii & Tree & $\mathrm{x}$ & & & $\mathrm{x}$ & $\mathrm{x}$ & $\mathrm{x}$ & $\mathrm{x}$ & $\mathrm{x}$ & $\mathrm{x}$ \\
\hline & Bursera xochipalensis & Tree & & $\mathrm{x}$ & & $\mathrm{x}$ & $\mathrm{x}$ & $\mathrm{x}$ & $\mathrm{x}$ & & $\mathrm{x}$ \\
\hline \multirow[t]{3}{*}{ Cactaceae } & Neobuxbaumia mezcalaensis & Shrub & $\mathrm{x}$ & & $\mathrm{x}$ & $\mathrm{x}$ & $\mathrm{x}$ & $\mathrm{x}$ & $\mathrm{x}$ & $\mathrm{x}$ & \\
\hline & Opuntia sp. & Shrub & $\mathrm{x}$ & $\mathrm{x}$ & $\mathrm{x}$ & $\mathrm{x}$ & $\mathrm{x}$ & & & $\mathrm{x}$ & \\
\hline & Pachycereus weberi & Shrub & $\mathrm{x}$ & & & & & & & & \\
\hline Capparaceae & Capparis sp. & Tree & & & & & & $\mathrm{x}$ & & & \\
\hline Celastraceae & Wimmeria pubescens & Shrub & & & $\mathrm{x}$ & & & & $\mathrm{x}$ & & \\
\hline Convolvulaceae & Ipomoea pauciflora & Tree & $\mathrm{x}$ & $\mathrm{x}$ & $\mathrm{x}$ & $\mathrm{x}$ & $\mathrm{x}$ & & $\mathrm{x}$ & $\mathrm{x}$ & $\mathrm{x}$ \\
\hline \multirow[t]{5}{*}{ Euphorbiaceae } & Croton flavescens & Shrub & $\mathrm{x}$ & & & & & & & & \\
\hline & Dalembertia populifolia & Tree & & & & $\mathrm{x}$ & & & & & \\
\hline & Euphorbia schlechtendalii & Tree & & $\mathrm{x}$ & $\mathrm{x}$ & $\mathrm{x}$ & $\mathrm{x}$ & $\mathrm{x}$ & $\mathrm{x}$ & $\mathrm{x}$ & $\mathrm{x}$ \\
\hline & Euphorbia sp. & Shrub & $\mathrm{x}$ & & & & & & & & \\
\hline & Sebastiana pavoniana & Tree & & & & & $\mathrm{x}$ & & $\mathrm{x}$ & & $\mathrm{x}$ \\
\hline \multirow[t]{22}{*}{ Fabaceae } & Acacia angustissima & Shrub & & & & & & & $\mathrm{x}$ & & \\
\hline & Acacia cochliacantha & Tree & $\mathrm{x}$ & $\mathrm{x}$ & $\mathrm{x}$ & $\mathrm{x}$ & $\mathrm{x}$ & $\mathrm{x}$ & $\mathrm{x}$ & $\mathrm{x}$ & $\mathrm{x}$ \\
\hline & Acacia subangulata & Tree & & & $\mathrm{x}$ & & & & $\mathrm{x}$ & & \\
\hline & Calliandra eryophylla & Shrub & & & & & & $\mathrm{x}$ & & & \\
\hline & Desmanthus balsensis & Shrub & $\mathrm{x}$ & $\mathrm{x}$ & $\mathrm{x}$ & $\mathrm{x}$ & $\mathrm{x}$ & & $\mathrm{x}$ & $\mathrm{x}$ & \\
\hline & Lysiloma acapulcensis & Tree & $\mathrm{x}$ & $\mathrm{x}$ & $\mathrm{x}$ & & $\mathrm{x}$ & $\mathrm{x}$ & $\mathrm{x}$ & $\mathrm{x}$ & \\
\hline & Lysiloma divaricata & Tree & & & $\mathrm{x}$ & & & & & $\mathrm{x}$ & \\
\hline & Lysiloma tergemina & Tree & $\mathrm{x}$ & $\mathrm{x}$ & & $\mathrm{x}$ & $\mathrm{x}$ & $\mathrm{x}$ & $\mathrm{x}$ & $\mathrm{x}$ & $\mathrm{x}$ \\
\hline & Mimosa cf. goldmanii & Shrub & $\mathrm{x}$ & $\mathrm{x}$ & $\mathrm{x}$ & $\mathrm{x}$ & & & $\mathrm{x}$ & & \\
\hline & Mimosa polyantha & Shrub & $\mathrm{x}$ & $\mathrm{x}$ & $\mathrm{x}$ & $\mathrm{x}$ & $\mathrm{x}$ & $\mathrm{x}$ & $\mathrm{x}$ & $\mathrm{x}$ & $\mathrm{x}$ \\
\hline & Pithecellobium dulce & Tree & & & & & & & & $\mathrm{x}$ & \\
\hline & Zapoteca sp. & Shrub & & & & & $\mathrm{x}$ & & $\mathrm{x}$ & $\mathrm{x}$ & $\mathrm{x}$ \\
\hline & Brongniartia montalvoana & Tree & $\mathrm{x}$ & & $\mathrm{x}$ & $\mathrm{x}$ & & $\mathrm{x}$ & $\mathrm{x}$ & $\mathrm{x}$ & $\mathrm{x}$ \\
\hline & Eysenhardtia polystachya & Tree & & $\mathrm{x}$ & $\mathrm{x}$ & $\mathrm{x}$ & $\mathrm{x}$ & $\mathrm{x}$ & $\mathrm{x}$ & $\mathrm{x}$ & $\mathrm{x}$ \\
\hline & Gliricidia sepium & Shrub & $\mathrm{x}$ & $\mathrm{x}$ & $\mathrm{x}$ & $\mathrm{x}$ & $\mathrm{x}$ & $\mathrm{x}$ & $\mathrm{x}$ & $\mathrm{x}$ & \\
\hline & Havardia acatlensis & Tree & $\mathrm{x}$ & $\mathrm{x}$ & $\mathrm{x}$ & $\mathrm{x}$ & $\mathrm{x}$ & $\mathrm{x}$ & $\mathrm{x}$ & $\mathrm{x}$ & $\mathrm{x}$ \\
\hline & Lonchocarpus sp. & Tree & & & & & $\mathrm{x}$ & & & $\mathrm{x}$ & \\
\hline & Pterocarpus acapulcensis & Tree & $\mathrm{x}$ & $\mathrm{x}$ & $\mathrm{x}$ & $\mathrm{x}$ & $\mathrm{x}$ & $\mathrm{x}$ & $\mathrm{x}$ & $\mathrm{x}$ & $\mathrm{x}$ \\
\hline & Pterocarpus orbiculatus & Tree & & & & $\mathrm{x}$ & & & & $\mathrm{x}$ & \\
\hline & Conzattia multiflora & Tree & & & & & & & & & $\mathrm{x}$ \\
\hline & Senna skineri & Shrub & & & $\mathrm{x}$ & & & & & & \\
\hline & Senna wislizeni & Shrub & $\mathrm{x}$ & $\mathrm{x}$ & $\mathrm{x}$ & $\mathrm{x}$ & $\mathrm{x}$ & $\mathrm{x}$ & $\mathrm{x}$ & & $\mathrm{x}$ \\
\hline Krameriaceae & Krameria sp. & Shrub & & & & & & $\mathrm{x}$ & & & \\
\hline
\end{tabular}


Table 1. Continues

\begin{tabular}{|c|c|c|c|c|c|c|c|c|c|c|c|}
\hline \multirow[t]{2}{*}{ Family } & \multirow[t]{2}{*}{ Species } & \multirow[t]{2}{*}{ Life form } & \multicolumn{3}{|c|}{$E S$} & \multicolumn{3}{|c|}{$I S$} & \multicolumn{3}{|c|}{$M S$} \\
\hline & & & 1 & 2 & 3 & 1 & 2 & 3 & 1 & 2 & 3 \\
\hline Loganiaceae & Plocosperma buxifolium & Shrub & $\mathrm{x}$ & $\mathrm{x}$ & $\mathrm{x}$ & & $\mathrm{x}$ & $\mathrm{x}$ & & $\mathrm{x}$ & $\mathrm{x}$ \\
\hline Malpighiaceae & Galphimia montana & Tree & $\mathrm{x}$ & & & & & & & & \\
\hline Malvaceae & Abutilon abutiloides & Shrub & & & & & & $\mathrm{x}$ & & & $\mathrm{x}$ \\
\hline \multirow[t]{2}{*}{ Moraceae } & Ficus cotinifolia & Tree & & $\mathrm{x}$ & & $\mathrm{x}$ & & & & & \\
\hline & Ficus sp. & Tree & & & & & & & $\mathrm{x}$ & & \\
\hline Olacaceae & Schoepfia schreberi & Shrub & & & & & $\mathrm{x}$ & & & & \\
\hline Opiliaceae & Agonandra racemosa & Shrub & & & & & & & & $\mathrm{x}$ & \\
\hline Polygonaceae & Ruprechtia fusca & Tree & & $\mathrm{x}$ & $\mathrm{x}$ & $\mathrm{x}$ & & $\mathrm{x}$ & & & $\mathrm{x}$ \\
\hline \multirow[t]{2}{*}{ Rhamnaceae } & Ziziphus amole & Tree & & & & & & $\mathrm{x}$ & $\mathrm{x}$ & & $\mathrm{x}$ \\
\hline & Ziziphus mexicana & Tree & & $\mathrm{x}$ & & $\mathrm{x}$ & $\mathrm{x}$ & $\mathrm{x}$ & $\mathrm{x}$ & $\mathrm{x}$ & $\mathrm{x}$ \\
\hline \multirow[t]{5}{*}{ Rubiaceae } & Exostema caribaeum & Shrub & & $\mathrm{x}$ & $\mathrm{x}$ & $\mathrm{x}$ & $\mathrm{x}$ & $\mathrm{x}$ & & $\mathrm{x}$ & $\mathrm{x}$ \\
\hline & Hintonia latiflora & Tree & $\mathrm{x}$ & & $\mathrm{x}$ & & & & $\mathrm{x}$ & & \\
\hline & Hintonia standleyana & Tree & $\mathrm{x}$ & & $\mathrm{x}$ & & & & $\mathrm{x}$ & & \\
\hline & Randia obcordata & Tree & $\mathrm{x}$ & $\mathrm{x}$ & $\mathrm{x}$ & & $\mathrm{x}$ & & & $\mathrm{x}$ & $\mathrm{x}$ \\
\hline & Randia sp. & Shrub & & & & $\mathrm{x}$ & & & & & \\
\hline Sapindaceae & Dodonaea viscosa & Tree & $\mathrm{x}$ & & & & & & & & \\
\hline Sapotaceae & Sideroxylon capiri & Tree & $\mathrm{x}$ & & & & & & & & \\
\hline Theophrastaceae & Jacquinia pungens & Shrub & & $\mathrm{x}$ & $\mathrm{x}$ & & & & & & \\
\hline Verbenaceae & Lantana camara & Shrub & & & & $\mathrm{x}$ & & & $\mathrm{x}$ & & \\
\hline Vitaceae & Cissus sp. & Shrub & $\mathrm{x}$ & $\mathrm{x}$ & $\mathrm{x}$ & $\mathrm{x}$ & $\mathrm{x}$ & $\mathrm{x}$ & $\mathrm{x}$ & $\mathrm{x}$ & $\mathrm{x}$ \\
\hline Simaroubaceae & Alvaradoa amorphoides & Tree & $\mathrm{x}$ & $\mathrm{x}$ & & & & & & $\mathrm{x}$ & \\
\hline Solanaceae & Datura candida & Shrub & & & & & & & & $\mathrm{x}$ & \\
\hline Sterculiaceae & Physodium dubium & Shrub & & & & & $\mathrm{x}$ & & $\mathrm{x}$ & $\mathrm{x}$ & \\
\hline
\end{tabular}

Gliricidia sepium, Cordia sp., Cissus sp., Havardia acatlensis, Mimosa goldmanii, Senna wislizeni, Acacia cochliacantha, Ipomoea pauciflora, Ceiba parvifolia, Bursera longipes and Alvaradoa amorphoides had the highest RIV the ES sites (Appendix 1). In IS, the species with higher RIV were Lysiloma tergemina, Exostema caribaeum, B. longipes, B. morelensis, B. vejarvazquezii, B. aptera, Pterocarpus acapulcensis, Cordia sp. and Euphorbia schlechtendalii (Appendix 1). Desmanthus balsensis, Mimosa polyantha, M. goldmanii, L. tergemina, Pseudosmodingium perniciosum, A. cochliacantha, E. schlechtendalii and species of the genus Bursera, $B$. longipes, B. aptera, B. morelensis, $B$. vejarvazquezii and $B$. submoniliformis had the highest values in MS (Appendix 1). Species richness, abundance and diversity. The species richness was similar between the intermediate and mature stages, with MS2 having the highest number of species (44, Table 2). The number of trees was lower than the number of shrubs in the ES while the reverse was true for the IS and MS (Table 2). On average we found $83 \%$ of the expected species according to the Chao2 estimator (ranging from $67.2 \%$ to $92.6 \%$ in ES1 and MS3; Table 2). There were less tree species in the ES sites than in both MS and IS. For each successional stage, we obtained on average $90.4 \%$ of the total expected. The mature stage had the highest species richness (Table 2). The higher rarefied species richness was found in mature forest. Contrary to what was expected, the early stages had more species in comparison to intermediate stages (Table 2).

The Shannon-Wiener index was higher in the IS sites (Fig. 2a), particularly in IS2 $(2.6 \pm 0.05)$, and lower in the ES, with the least diverse site being ES1 $(1.9 \pm 0.10)\left(\chi^{2}=\right.$ $38.39, d f=8, p<0.001)$. The Simpson's dominance index was higher for the ES because the high importance values of a few species (e.g., G. sepium, L. tergemina, Cissus sp., Cordia sp.) made these sites less homogeneous $\left(\chi^{2}=\right.$ 
Table 2. Species richness (observed, expected and rarefied) and abundance of woody plants for nine sites in 3 tropical dry forest successional stages in Guerrero

\begin{tabular}{|c|c|c|c|c|c|c|c|c|}
\hline Sites & $\begin{array}{c}\text { Shrub } \\
\text { species }\end{array}$ & $\begin{array}{c}\text { Tree } \\
\text { species }\end{array}$ & $\begin{array}{c}\text { Total } \\
\text { species } \\
\text { observed }\end{array}$ & $\begin{array}{c}\text { Total } \\
\text { species } \\
\text { expected }\end{array}$ & $\begin{array}{c}\text { Total } \\
\text { species } \\
\text { rarefied }\end{array}$ & $\begin{array}{c}\text { Individuals } \\
\text { Shrub }\end{array}$ & $\begin{array}{c}\text { Individuals } \\
\text { Tree }\end{array}$ & $\begin{array}{c}\text { Total } \\
\text { individuals } \\
\text { observed }\end{array}$ \\
\hline ES1 & 13 & 24 & 37 & 55 & 35 & 245 & 146 & 391 \\
\hline ES2 & 11 & 24 & 35 & 40 & 35 & 179 & 176 & 355 \\
\hline ES3 & 15 & 26 & 41 & 45 & 38 & 278 & 202 & 480 \\
\hline ES1-3 & 18 & 39 & 57 & 65 & 57 & 702 & 524 & 1226 \\
\hline IS1 & 12 & 29 & 41 & 51 & 39 & 104 & 319 & 423 \\
\hline IS2 & 14 & 29 & 43 & 51 & 38 & 111 & 595 & 706 \\
\hline IS3 & 11 & 31 & 42 & 60 & 35 & 157 & 516 & 673 \\
\hline IS1-3 & 20 & 39 & 59 & 65 & 55 & 372 & 1430 & 1802 \\
\hline MS1 & 13 & 30 & 43 & 47 & 39 & 233 & 348 & 581 \\
\hline MS2 & 14 & 30 & 44 & 64 & 39 & 124 & 464 & 588 \\
\hline MS3 & 8 & 30 & 38 & 41 & 37 & 45 & 378 & 423 \\
\hline MS1-3 & 20 & 45 & 65 & 71 & 60 & 402 & 1190 & 1592 \\
\hline
\end{tabular}

38.63, $d f=8, p<0.001)$. The opposite was true in the IS and MS sites (Fig. 2b). Evenness, therefore, was lower in $\operatorname{ES}\left(\chi^{2}=26.29, d f=8, p<0.001\right.$; Fig. 2c). In general, Mann-Whitney multiple comparisons revealed that the early sites and stages were statistically different from the intermediate and mature stages ( $p<0.05$, Figs. 2a-c).

Vegetation structure. Plant density (ind/ha) was higher in IS2 $(157.5 \pm 6.63)$ and IS3 $(158.7 \pm 13.73)$, and lower in the 3 ES sites (Fig. 3a). Total plant cover was higher in the intermediate stages (Fig. 3b), particularly in IS3 (711.7 \pm 58.22) and lower in ES with ES1 having the lowest values $(326.2 \pm 31.23)$. FHD was more intricate in 2 intermediate sites $(\mathrm{IS} 3=1.7 \pm 0.06$ and $\mathrm{IS} 1=1.6 \pm 0.04)$ and MS2 $(1.5 \pm$ $0.07)$, reflecting the mixture of trees and shrubs of different sizes in these successional stages (Fig. 3c). Plant density and cover were significantly different between successional stages $\left(F_{8,114}=17.50, p<0.001\right.$ and $\left.F_{8,114}=28.18, p<0.001\right)$, while FHD was different between sites $\left(F_{8,114}=13.63, p<\right.$ $0.001)$ and successional stages $\left(F_{8,114}=19.16, p<0.001\right)$. The interaction between sites and seral stages was not significant. The results of post hoc Tukey HSD tests indicated that the density of the ES was lower compared with the IS and MS (Fig. 3a). Cover and FHD were significantly different between the 3 stages ( $p<0.05$, Figs. 3b-c).

Species distribution. At a distance of $66.7 \%$, the critical level of flora separation according to Sánchez and López (1988), the dendrogram classified sites into 3 groups (Fig. 4). The first consists of the $3 \mathrm{ES}$, the second includes the 3 IS and MS2 and MS3, and the third is represented by the MS1. A multiple discriminant showed that the 3 groups were significantly different (function 1: $\lambda=0.000$, $\chi^{2}=73.31, d f=12, p<0.001$; function $2: \lambda=0.000, \chi^{2}=$ $32.98, d f=5, p<0.001)$.
The CA coincides with the classification. The first axis (eigenvalue $=0.446,46.1 \%$ cumulative variance) separated the ES from MS and IS and the second axis (eigenvalue= 0.159 , cumulative variance $62.5 \%$ ), separated MS1 from all the others (Fig. 5). Pseudosmodingium perniciosum, $P$. andrieuxii, Eysenhardtia polystachya and $E$. schlechtendalii were associated with MS3. Desmanthus balsensis, Acacia subangulata and Zapoteca sp. with MS1. Gliricidia sepium, A. amorphoides, S. wislizenni, Cissus sp., H. acatlensis, M. goldmanii, which are typical of open areas were found in ES, together with Bursera grandifolia and I. pauciflora. Finally, most of Bursera species (B. longipes, B. morelensis, B. aptera, $B$. fagaroides, B. chemapodicta, B. suntui, B. lancifolia, $B$. mirandae, B. xochipalensis, B. vejarvazquezii and $B$. submoniliformis) were associated with MS2 and the 3 intermediate stages.

\section{Discussion}

Floristic composition. The species richness was low (83 species) compared to the numbers reported for other dry forest within the Balsas basin (e.g., Trejo and Dirzo, 2002; Carreto and Almazán, 2004), other regions of Mexico (e.g., Lott and Atkinson, 2002; Gallardo-Cruz et al., 2005), and Central and South America (Killeen et al., 1998; Gillespie et al., 2000; Kalacksa et al., 2004; Powers et al., 2009). However, in this study we only included plants with DBH $\geq 10 \mathrm{~cm}$. Furthermore, the observed number of species was close to the expected richness according to the estimator Chao2.

At the family level, Fabaceae was the best represented, both in the number of species and individuals. This is 
consistent with what has been reported in other TDF of the Neotropics (Gentry, 1995; Gillespie et al., 2000). The second family with high species richness was Burseraceae. The Balsas basin is considered to be the center of the diversity and endemism of the genus Bursera (Rzedowski et al., 2005; De-Nova et al., 2012).

Richness, abundance and diversity. The differences in species richness, abundance and diversity of woody plants was mainly between the ES and the IS and MS sites. Interestingly, in ES, where the intensity of the disturbance
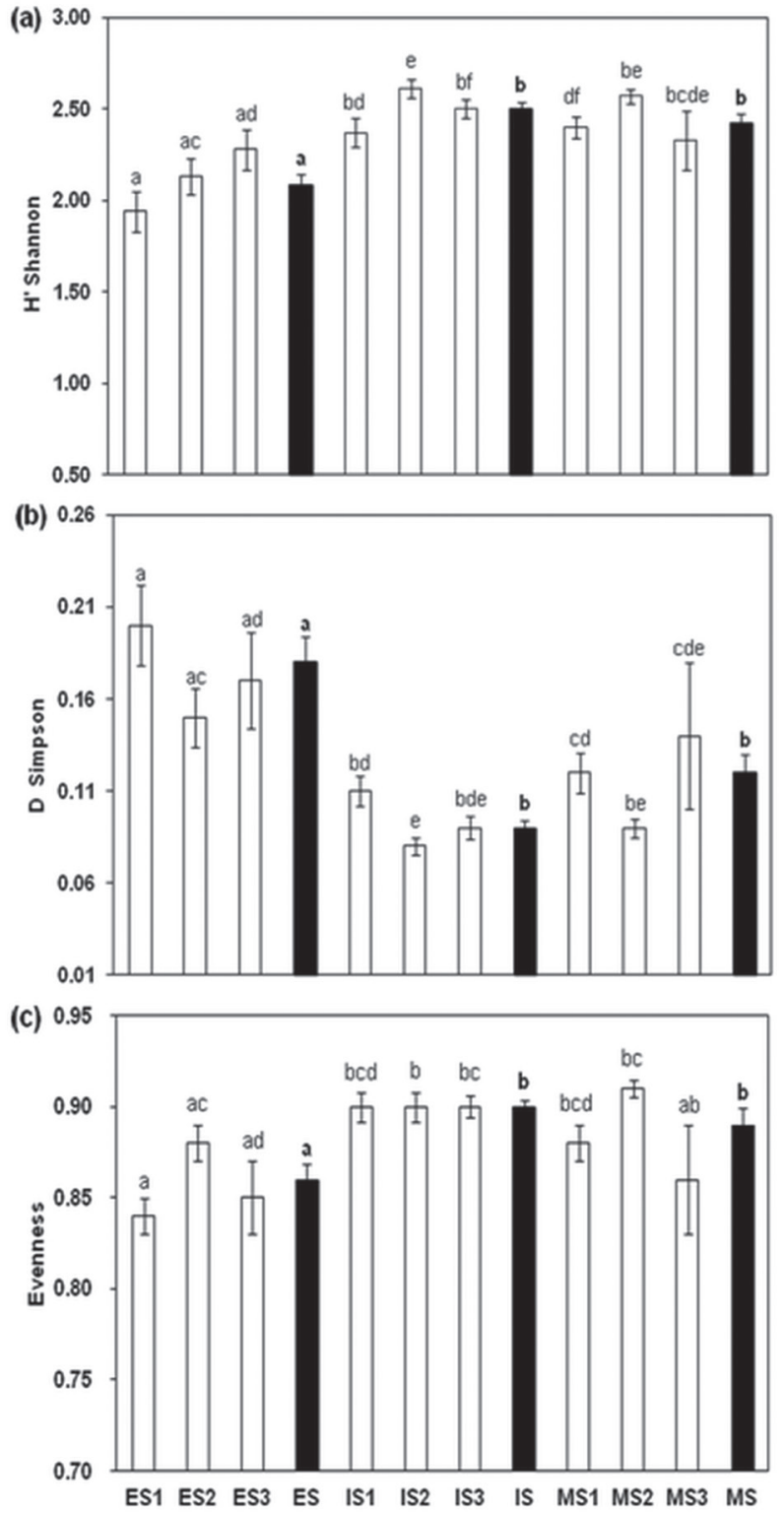

Figure 2. Diversity indices mean values $( \pm \mathrm{SE})$ from nine sites (open bars) and 3 successional stages (shaded bars) of a tropical dry forest in Guerrero, Mexico. Different letters denote significant differences $(p<0.05)$ according to Mann-Whitney U test. was similar, the dominant pioneer species were the same in the 3 sites: Gliricidia sepium, Cissus sp. and Cordia sp. These species are indicative of secondary succession and have a high capacity to colonize degraded areas (Leirana et al., 2009; Griscom and Ashton, 2011).

In the study area, the ES sites had open canopies. This results in pronounced microclimatic changes and low water retention, which hampers the germination and establishment of typical of mature forests species (e.g., plants of the genus Bursera) (Walker et al., 1996, 2007; Balvanera and Aguirre,
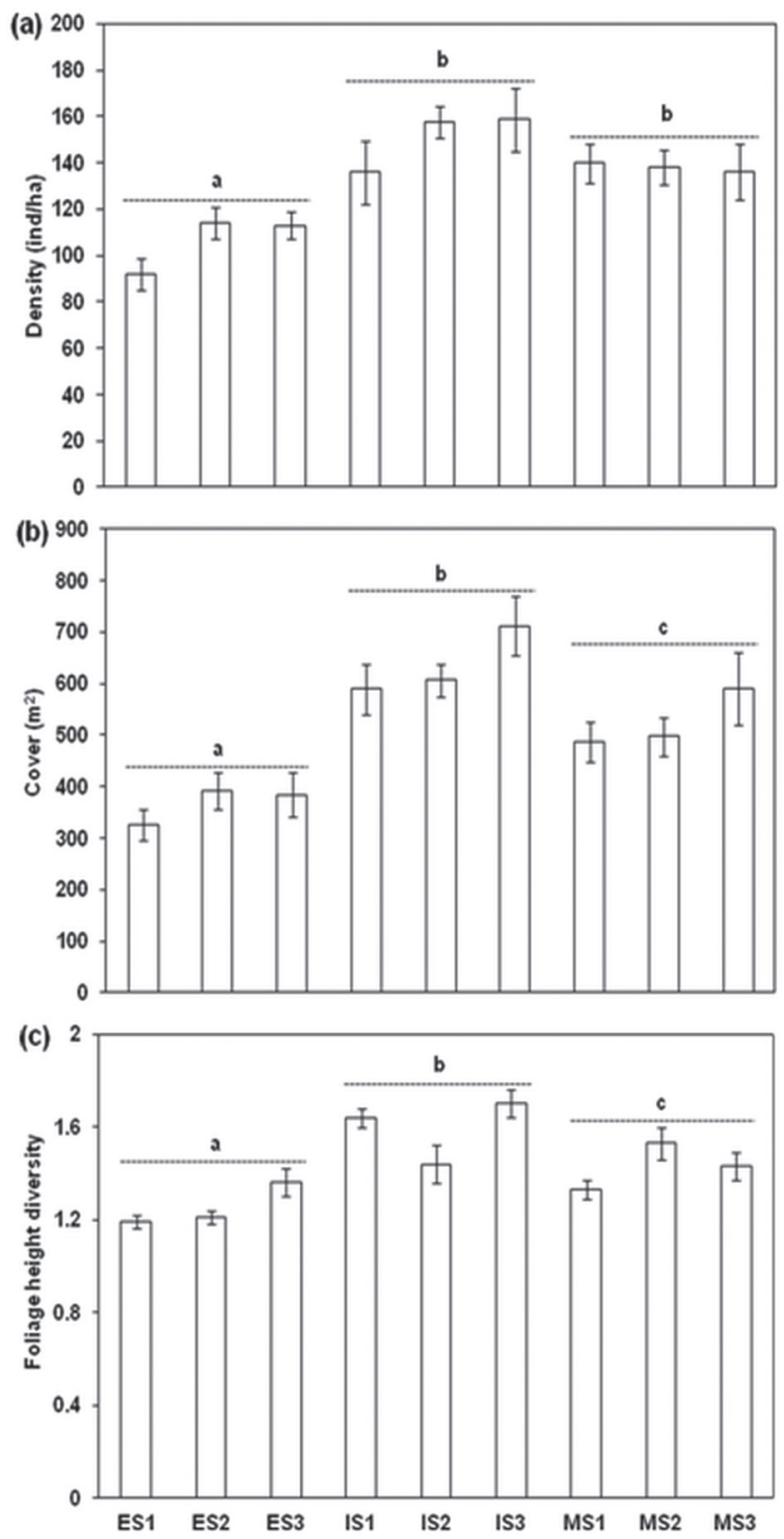

Figure 3. Mean values $( \pm \mathrm{SE})$ of the vegetation structural characteristics for nine sites in 3 tropical dry forest successional stages in Guerrero, Mexico. Different letters denote significant differences $(p<0.05)$ according to Tukey HSD test. 


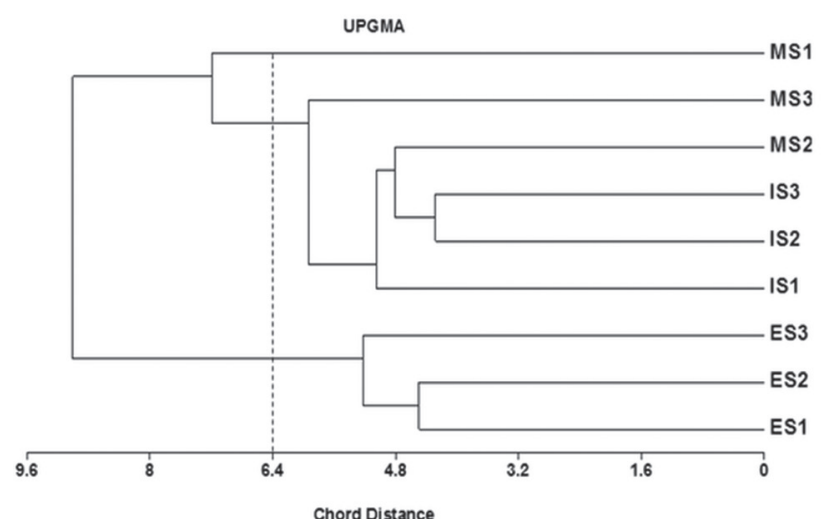

Figure 4. Classification of nine tropical dry forest sites using RIV values and the Chord distance as a measure of dissimilarity. The dotted line represents the $66.7 \%$ cutoff level suggested by Sánchez and López (1988).

2006; Ceccon et al., 2006), which were present but rare. Under these conditions the germination of these plants may take very long time periods (Vázquez-Yanez and OrozcoSegovia, 1993), especially when phenology, as is the case of TDF, is strongly influenced by climatic seasonality. Seed dispersal may also explain the low numbers of mature forest species in the early stages (Kennard et al., 2002; Ceccon et al., 2006). It is possible that secondary forests are undergoing a reassembly of canopy trees by means of the successful recruitment of seedlings and young trees of mature forest species (Norden et al., 2009). According to the initial floristic composition hypothesis (Egler, 1954), most TDF species may be found in all successional stages, but recruitment from MS could be lower in ES because many require frugivores for their dispersal. Studies in tropical dry forests of Central America have shown that in early successional stages where the seed bank is severely depleted or absent, anemochory is more common than zoochory (Janzen, 1988b; Sabogal, 1992). This is because many frugivores avoid visiting small remnants of early stages (Uhl et al., 1988). Different studies in Mexico and other regions also support the initial floristic composition hypothesis (Finegan, 1996; van Bruegel et al., 2006; Chazdon, 2008).

On the other hand, the ILD hypothesis (Connell, 1978; Collins and Glenn, 1997; Bongers et al., 2009) was not supported by our results, since species richness of early and mature stages was higher or equal to intermediate successional sites and stages. Furthermore, species typical of TDF (e. g., C. parvifolia, Cordia sp., $B$. longipes, L. tergemina, M. polyantha, $H$. acatlensis, E. caribaeum) were constant across the chronosequence (Aravena et al., 2002). The species similarity can be best explained by the initial floristic composition model (Egler, 1954; Collins et al., 1995), which predicts that the composition and community structure of plants change

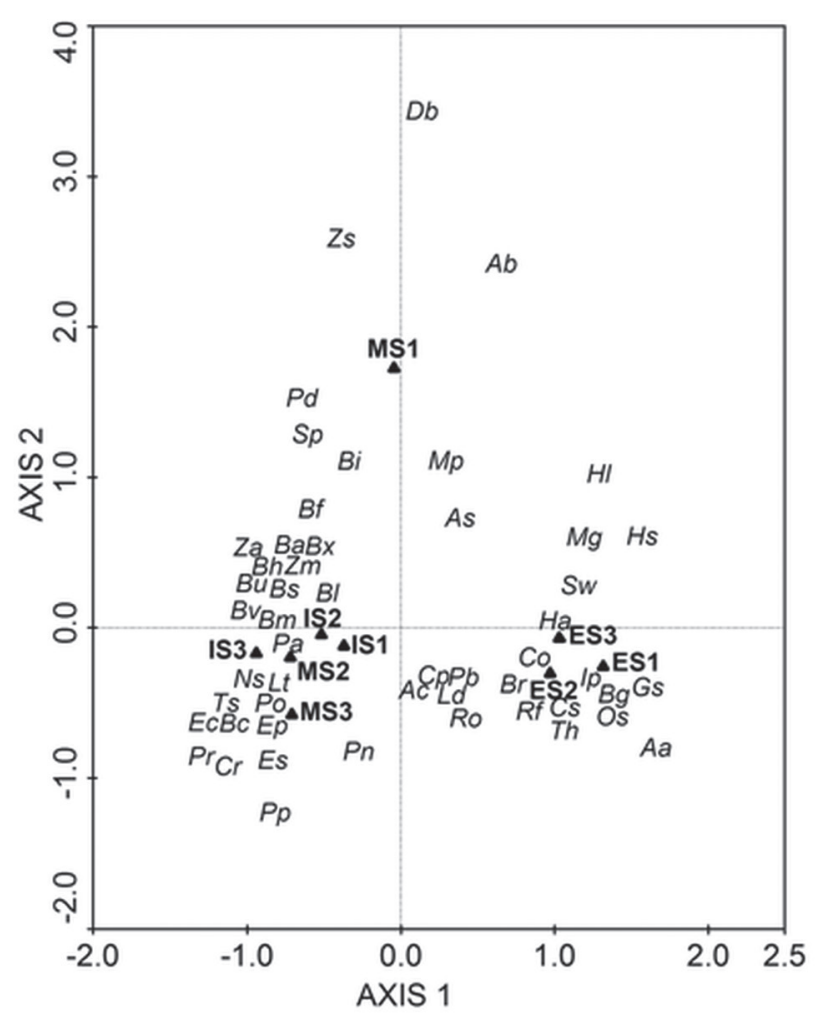

Figure 5. Correspondence analysis using RIV values of the plant species found in nine sites corresponding to 3 successional stages in Organera-Xochipala, Guerrero. Sw: Senna wislizenni, Mg: Mimosa goldmanii, Mp: M. polyantha, Ha: Havardia acatlensis, Os: Opuntia sp., Cs: Cissus sp., Ac: Acacia cochliacantha, Ab: A. subangulata, Gs: Gliricidia sepium, Ro: Randia obcordata, Br: Brongniartia montalvoana, Th: Thevetia sp., Bg: Bursera grandifolia, Bl: B. longipes, Bf: B. fagaroides, $\mathrm{Bm}$ : B, morelensis, $\mathrm{Ba}$ : B. aptera, $\mathrm{Bv}$ : $B$. vejarvazquezii, $\mathrm{Bi}: B$. mirandae, $\mathrm{Bx}$ : B. xochipalensis, $\mathrm{Bu}$ : B. submoniliformis, $\mathrm{Bh}$ : $B$. schlechtendalii, Bs: B. suntui, Bc: B. chemapodicta, Ns: $N$. mezcalaensis, Lt: Lysiloma tergemina, Ld: L. divaricata, As: L. acapulcensis, Db: Desmanthus balsensis, $\mathrm{Pb}$ : Plocosperma buxifolium, Cp: Ceiba parvifolia, Aa: Alvaradoa amorphoides, Csp: Cordia sp., Ip: Ipomoea pauciflora, Hl: Hintonia latiflora, Hs: Hintonia standleyana, Pa: Pterocarpus acapulcensis, Po: P. orbiculatus, Rf: Rupretchia fusca, Ec. Exostema caribaeum, Zm: Ziziphus mexicana, Za: Z. amole, Es: Euphorbia schlechtendalii, Pp: Pseudosmodigium perniciosum, Pn: P. andrieuxii, Ep: Eysenhardtia polystachia, Ts: Tecoma stans, Cpr: Cytocarpa procera, Pd: Physodium dubium, Zs: Zapoteca sp., Pr: Plumeria rubra, Sp: Sebastiana pavoniana.

gradually, without a total replacement of one community for another.

Dominance was higher and evenness was lower in the ES stands. This is a typical pattern of disturbed communities in which pioneer species achieve high relative importance values in relation to other species (Onaindia et al., 2004; Bongers et al., 2009; Sapkota et al., 
2010). In contrast, both indices were similar between the IS sites and MS2. This would be if the late stages in the study site had been subject to some degree of perturbation (and may be best described as secondary forests in an advanced stage of regeneration), as has been described for other dry forests of Mexico (Kalacska et al., 2005) and the Neotropics (Madeira et al., 2009). If this is true, the species richness similarity between IS and MS could change in the next decades.

In addition to the dispersal strategies, the species composition and succession dynamics are also affected by soil conditions, topography and microclimate (Tansley, 1935; Jha and Singh, 1990; Kalacksa et al., 2004; Ceccon et al., 2006; Davies and Semui, 2006; Griscom and Ashton, 2011). The fact that different species were dominant in density in the MS sites (e.g., D. balsensis in MS1, $L$. tergemina in MS2 and P. perniciosum in MS3) suggests that each had particular specific local conditions that determined the final composition. Desmanthus balsensis, for example, is endemic to the Balsas Guerrero portion and relatively common on slopes with calcareous soils (Contreras et al., 1986). Lysiloma tergemina is particularly abundant in areas dominated by shales and sandstones with Kastanozems type soils, while $P$. perniciosum develops in areas of igneous rocks and soil type Feozem (Boyás, 1992). These edaphic conditions are present along the Balsas basin and correspond to each of the 3 study sites (Peralta, 1995).

Microclimatic variation also influences the variability of species composition in mature stages of succession primarily. Murphy and Lugo (1986) analyzed 18 tropical dry forests of different regions of the planet and found a high beta diversity among study sites attributed to climatic factors. Soil and microclimatic changes probably explained the differences in species composition between the mature sites shown in the multivariate analyses results.

Vegetation structure. The highest average density (ind/ha) was in the IS and lowest in the ES. The number of large sized individuals $(\mathrm{DBH}>30 \mathrm{~cm})$ increases asymptotically with forest age (Peet and Christensen, 1980; Madeira et al., 2009). In the early stages, recruitment depends on a few seedlings that manage to colonize the unfavorable conditions. As succession proceeds, a high number of young trees coexisted in the intermediate stages which are later displaced in the mature stages of succession by larger tree classes which overall reduce the plant densities.

Both, cover and FHD were also higher in IS. These results do not correspond to the general patterns observed in other wet and dry forests, since these are characterized by tall mature trees with large foliage coverage (Chapman and Chapman, 1990; Kalacska et al., 2004; Sánchez-
Gallen et al., 2010). In comparison to IS, the lower tree cover in MS may be explained by a higher stratification complexity and the presence of some shrubs and trees (i.e., P. acapulcensis and E. caribaeum) with well structured canopies.

Conclusions and implications for conservation. In addition to the floristic and structural data, studies focused on the analysis of successional processes and the effects they have on tropical dry forests, should be considered in the design of management and conservation programs (Sánchez-Azofeita et al., 2005; Wright, 2005). The description of the composition and structure of the different successional stages is the preliminary stage to understand and assess successional dynamics of the vegetation communities. In addition, the study of early and intermediate stages is particularly important because historical records show that mature stages over time will eventually disappear leaving a matrix of agricultural fields and forest patches at different stages of succession (Quesada et al., 2009).

The results of this study show that mature and intermediate forests had similar alpha diversity values as the early stages. In addition, by having several replicas, we were able to identify structural and floristic changes within and between successional stages. The seed bank, potential propagules from adjoining areas and dispersal agents may all explain the species turnover throughout the chronosequence described in this study and our approach allowed us to show that beta diversity is particularly relevant in mature forests. Because of this, conservation efforts and management plans should not be directed to only single mature forests stands, but should include areas exposed to different microclimate and soil conditions, as well as sites represented by earlier seral stages in order to ensure the conservation of biodiversity at a regional level.

\section{Acknowledgements}

R. C. Almazán-Núñez would like to thank R. Bahena, M. T. Cruz and numerous undergraduate students from the Universidad Autónoma de Guerrero for their help in the field. N. Diego, R. M. Fonseca and the staff of the Laboratorio de Plantas Vasculares de la Facultad de Ciencias, UNAM that determined the botanical specimens collected. The authors thank two anonymous reviewers for their comments on an earlier version of the manuscript. Financial support was provided by DGAPA-PAPIIT No. IN217511, IN210908 and CONABIO HQ00 projects. R. C. Almazán-Núñez was supported by a Ph.D. CONACYT (165552; Consejo Nacional de Ciencia y Tecnología) grant and the Universidad Autónoma Metropolitana. 


\section{Literature cited}

Aide, T. M., J. K. Zimmerman, J. B. Pascarella, L. Rivera and H. Marcano-Vega. 2000. Forest regeneration in a chronosequence of tropical abandoned pastures: implications for restoration ecology. Restoration Ecology 8:328-338.

Álvarez-Yépiz, J. C., A. Martinez-Yrizar, A. Burquez and C. Lindquist. 2008. Variation in vegetation structure and soil properties related to land use history of old-growth and secondary tropical dry forests in northwestern Mexico. Forest Ecology and Management 256:355-366.

Aravena, J. C., M. R. Carmona, C. A. Pérez and J. J. Armesto. 2002. Changes in tree species richness, stand structure and soil properties in a successional chronosequence in northern Chiloé Island, Chile. Revista Chilena de Historia Natural 75:339-360.

Balvanera, P. and E. Aguirre. 2006. Tree diversity, environmental heterogeneity, and productivity in a Mexican tropical dry forest. Biotropica 38:479-491.

Bongers, F., L. Poorter, W. D. Hawthorne and D. Sheil. 2009. The intermediate disturbance hypothesis applies to tropical forests, but disturbance contributes little to tree diversity. Ecology Letters 12:1-8.

Boyás, J. 1992. Determinación de la productividad, composición y estructura de las comunidades arbóreas del Estado de Morelos en base a unidades ecológicas. Ph. D. thesis, Facultad de Ciencias, UNAM. México, D.F. 285 p.

Brower, J. E., J. H. Zar and C. N. von Ende. 1998. Field and laboratory methods for general ecology. Fourth ed. WCBMcGraw-Hill, Boston. 273 p.

Carreto, B. E and A. Almazán. 2004. Vegetación en la laguna de Tuxpan y alrededores. In Estudios florísticos en Guerrero, N. Diego-Pérez and R. M. Fonseca (eds.). Facultad de Ciencias, UNAM. México, D. F. p. 1-30.

Ceccon, E., P. Huante and E. Rincón. 2006. Abiotic factors influencing tropical dry forests regeneration. Brazilian Archives of Biology and Technology 49:305-312.

Chazdon, R. L. 2008. Chance and determinism in tropical forest succession. In Tropical forest community ecology, W. Carson and S. A. Schnitzer (eds.). Wiley-Blackwell Publishing. Oxford, p. 384-408

Collins, S. L. and S. M. Glenn. 1997. Intermediate disturbance and its relationship to within- and between-patch dynamics. New Zealand Journal of Ecology 21:103-110.

Collins, S. L., S. M. Glenn and D. J. Gibson. 1995. Experimental analysis of intermediate disturbance and initial floristic composition: decoupling cause and effect. Ecology 76:486492.

Colwell, R. K. 2006. EstimateS: statistical estimation of species richness and shared species from samples. Version 8. URL: http//viceroy.eeb.uconn.edu/estimates.
Colwell, R. K. and J. A. Coddington. 1994. Estimating terrestrial biodiversity. Philosophical Transactions of the Royal Society of London Series B 345:101-118

Connell, J. H. 1978. Diversity in tropical rain forests and coral reefs. Science 199:1302-1310.

Connell, J. H and R. O. Slatyer. 1977. Mechanisms of succession in natural communities and their role in community stability and organization. American Naturalist 111:1119-1144.

Contreras, J. L. 1986. Desmanthus balsensis (Leguminosae: Mimosoideae). Una especie nueva de la depresión del río Balsas en Guerrero, México. Phytologia 60:89-92.

Chapman, C. A. and L. J. Chapman. 1990. Density and growth rate of some tropical dry forest trees: Comparisons between successional forest types. Bulletin of the Torrey Botanical Society 117:226-231.

Davies, J. S. and H. Semui. 2006. Competitive dominance in a secondary successional rain-forest community in Borneo. Journal of Tropical Ecology 22:53-64.

DeClerck, F. A. J., R. Chazdon, K. D. Holl, J. C. Milder, B. Finegan, A. Martínez-Salinas, P. Imbach, L. Canet and Z. Ramos. 2010. Biodiversity conservation in humanmodified landscapes of Mesoamerica: Past, present and future. Biological Conservation 143:2301-2313.

De-Nova, A., R. Medina, J. C. Montero, A. Weeks, J. A. Rosell, M. E. Olson, L. E. Eguiarte and S. Magallón. 2012. Evolutionary diversification in species-rich mesoamerican seasonally dry tropical forests: Bursera (Burseraceae, Sapindales) as a case study. New Phytologist 193:276-287.

Egler, F. E. 1954. Vegetation science concepts I. Initial floristic composition - a factor in old-field vegetation development. Vegetatio 4:412-417.

Finegan, B. 1996. Pattern and process in neotropical secondary rain forests: The first 100 years of succession. Trends in Ecology and Evolution 11:119-124.

Gallardo-Cruz, J. A., J. A. Meave and E. A. Pérez-García. 2005. Estructura, composición y diversidad de la selva baja caducifolia del Cerro Verde, Nizanda (Oaxaca), México. Boletín de la Sociedad Botánica de México 76:19-35.

Gentry, A. H. 1995. Diversity and floristic composition of neotropical dry forests. In Seasonally dry tropical forests, S. H. Bullock, H. A. Mooney and E. Medina. (eds.). Cambridge University Press, Cambridge. p. 146-194.

Gillespie, T. W., A. Grijalva and C. N. Farris. 2000. Diversity, composition, and structure of tropical dry forests in Central America. Plant Ecology 147:37-47.

Grime, J. P. 1973. Control of species density in herbaceous vegetation. Journal of Environmental Management 1:151167.

Griscom, H. P. and M. S. Ashton. 2011. Restoration of dry tropical forests in Central America: A review of pattern and process. Forest Ecology and Management 161:1564-1579.

Janzen, D. H. 1988a. Management of habitat fragments in 
a tropical dry forest: Growth. Annals of the Missouri Botanical Garden 75:105-116.

Janzen, D. H. 1988b. Tropical dry forests: the most endangered major ecoystem. In Biodiversity, E. O. Wilson (ed.). National Academic Press. Washington. p. 130-137.

Jha, C. S. and S. J. Singh. 1990. Composition and dynamics of dry tropical forest in relation to soil texture. Journal of Vegetation Science 1:609-614.

Kalacska, M., G. A. Sánchez-Azofeita, J. C. Calvo-Alvarado, M. Quesada, B. Rivard and D. H. Janzen. 2004. Species composition, similarity and diversity in three successional stages of a seasonally dry tropical forest. Forest Ecology and Management 200:227-247.

Kalacska, M., G. A. Sánchez-Azofeita, J. C. Calvo-Alvarado, B. Rivard and M. Quesada. 2005. Effects of season and successional stage on leaf area index and spectral vegetation indices in three Mesoamerican tropical dry forest. Biotropica 37:486-496.

Kayes, L. J., P. D. Anderson and K. J. Puettmann. 2010. Vegetation succession among and within structural layers following wildfire in managed forests. Journal of Vegetation Science 21:233-247.

Kennard, D. K. 2002. Secondary forest succession in a tropical dry forest: patterns of development across a 50-year chronosequence in lowland Bolivia. Journal of Tropical Ecology 18:53-66.

Killeen, T. J., A. Jardim, F. Mamani and N. Rojas. 1998. Diversity, composition and structure of a tropical semideciduous forest in the Chiquitanía region of Santa Cruz, Bolivia. Journal of Tropical Ecology 14:803-827.

Kovach, W. L. 2009. MVSP: a multivariate statistical package for Windows. Version 3.13r. Kovach Computing Services, Pentraeth, Wales. 133 p.

Legendre, P. and E. Gallagher. 2001. Ecologically meaningful transformations for ordination of species data. Oecologia 129:271-280

Leirana, J. L., S. Hernández-Betancourt, L. Salinas-Peba and L. Guerrero-González. 2009. Cambios en la estructura y composición de la vegetación relacionados con los años de abandono de tierras agropecuarias en la selva baja caducifolia espinosa de la reserva de Dzilam, Yucatán. Polibotánica 27:53-70.

Lott, E. J. and T. H. Atkinson. 2002. Diversidad y fitogeografía de Chamela-Cuixmala, Jalisco. In Historia Natural de Chamela, F. A. Noguera, J. H. Vega, A. N. García-Aldrete and M. Quesada (eds.). Instituto de Biología, UNAM. México, D. F. p. 83-97.

Madeira, B. G., M. M. Espírito-Santo, S. D. Neto, Y. R. F. Nunes, G. A. Sánchez-Azofeita, G. Wilson and M. Quesada. 2009. Changes in tree and liana communities along a successional gradient in a tropical dry forest in south-eastern Brazil. Plant Ecology 201:291-304.
McCabe, D. J. and N. J. Gotelli. 2000. Effects of disturbance frequency, intensity, and area on assemblages of stream macroinvertebrates. Oecologia 124:270-279.

Meza, L. and J. L. López. 1997. Vegetación y mesoclima de Guerrero. In Estudios florísticos en Guerrero, N. DiegoPérez and R. M. Fonseca (eds.). Facultad de Ciencias, UNAM. México, D. F. p. 1-53.

Montaña, C. and E. Ezcurra. 1980. Simple instrument for quick measurement of crown projections. Journal of Forestry 78:699.

Muller-Dombois, D. and H. Ellenberg. 1974. Aims and methods of vegetation ecology. John Wiley and Sons, New York. 547 p.

Murphy, P. G. and A. E. Lugo. 1986. Ecology of tropical dry forest. Annual Review of Ecology and Systematics 17:6788.

Onaindia, M., I. Dominguez, I. Albizu, C. Garbisu and I. Amezaga. 2004. Vegetation diversity and vertical structure as indicators of forest disturbance. Forest Ecology and Management 195:341-354.

Orlóci, L. 1978. Multivariate analysis in vegetation research. Second Ed. Junk, The Hague. 541 p.

Peet, R. K. and N. L. Christensen. 1980. Succession: a population process. Vegetatio 43:131-140.

Peralta, S. 1995. Cañón del Zopilote (área Papalotepec). In Estudios florísticos en Guerrero, N. Diego-Pérez and R. M. Fonseca (eds.). Facultad de Ciencias, UNAM. México, D. F. p. 1-37.

Powers, J. S., J. M. Becknell, J. Irving and D. Pèrez-Aviles. 2009. Diversity and structure of regenerating tropical dry forests in Costa Rica: Geographic patterns and environmental drivers. Forest Ecology and Management 258:959-970.

Prach, K. and L. R. Walker. 2011. Four opportunities for studies of ecological succession. Trends in Ecology and Evolution 26:119-123.

Quesada, M. and K. E. Stoner. 2004. Threats to the conservation of the tropical dry forest in Costa Rica. In Biodiversity conservation in Costa Rica: learning the lessons in a seasonal dry forest, G. W. Frankie, A. Mata and S. B. Vinson (eds.). University of California Press, Berkeley. p. 266-280.

Quesada, M., G. A. Sánchez-Azofeita, M. Álvarez-Añorve, K. E. Stoner, L. Avila-Cabadilla, J. Calvo-Alvarado, A. Castillo, M. M. Espírito-Santo, M. Fagundes, G. W. Fernandes, J. Gamon, M. Lopezaraiza-Mikel, B. Lawrence, L. P. Cerdeira, J. S. Powers, F. Neves, V. Rosas-Guerrero, R. Sayago and G. Sánchez-Montoya. 2009. Succession and management of tropical dry forests in the Americas: review and new perspectives. Forest Ecology and Management 258:1014-1024.

Pickett, S. T. A. and M. J. McDonnnell. 1989. Changing perspectives in community dynamics: a theory of successional forces. Trends in Ecology and Evolution $4: 241-245$. 
Roxburgh, S. H., K. Shea and J. Bastow. 2004. The intermediate disturbance hypothesis: patch dynamics and mechanisms of species coexistence. Ecology 85:359-371.

Rzedowski, J. 1978. Vegetación de México. Ed. Limusa. México, D. F. 432 p.

Rzedowski, J., R. Medina and G. Calderón. 2005. Inventario del conocimiento taxonómico, así como de la diversidad y del endemismo regionales de las especies mexicanas de Bursera (Burseraceae). Acta Botanica Mexicana 70:85-111.

Sabogal, C. 1992. Regeneration of tropical dry forests in central America, with examples from Nicaragua. Journal of Vegetation Science 3:407-416.

Sánchez, O. and G. López. 1988. A theoretical analysis of some indices of similarity as applied to biogeography. Folia Entomológica Mexicana 75:119-145.

Sánchez-Azofeita, G. A., M. Kalacska, M. Quesada, J. C. CalvoAlvarado, J. M. Nassar and J. P. Rodríguez. 2005. Need for integrated research for a sustainable future in tropical dry forests. Conservation Biology 19:285-286.

Sánchez-Gallen, I., F. J. Álvarez-Sánchez and J. BenítezMalvido. 2010. Structure of the advanced regeneration community in tropical rain forest fragments of Los Tuxtlas, Mexico. Biological Conservation 143:2111-2118.

Sapkota I. P., M. Tigabu and P. C. Oden. 2010. Changes in tree species diversity and dominance accross a disturbance gradient in Nepalese Sal (Shorea robusta Gaertn. f.) forests. Journal of Forestry Research 21:25-32

SPSS. 2008. SPSS for Windows. Release 17.0. Statistical Package for Social Sciences Inc, Chicago. 616 p.

Stevens, P. F. 2001. Angiosperm phylogeny website. Version 9, June 2008. http//mobot.org/MOBOT/research/APweb/; last access: 25.V.2010.

Stoner, K. E. and G. A. Sánchez-Azofeita. 2009. Ecology and regeneration of tropical dry forests in the Americas: Implications for management. Forest Ecology and Management 258:903-906.

Tansley, A. G. 1935. The use and abuse of vegetational concepts and terms. Ecology 16:284-307.

Ter Braak, C. J. J. and P. Smilauer. 2002. CANOCO Reference manual and CanoDraw for Windows user's guide: software for canonical community ordination (version 4.5). Ithaca. $500 \mathrm{p}$.

Trejo, I. and R. Dirzo. 2002. Floristic diversity of Mexican seasonally dry tropical forests. Biodiversity and Conservation 11:2063-2084.

Uhl, C., R. Buschbacher and E. A. Serrao. 1988. Abandoned pastures in eastern Amazonia. I. Patterns of plant succession. Journal of Ecology 73:663-681.

van Breugel, M., M. Martinez-Ramos and F. Bongers. 2006. Community dynamics during early secondary succession in Mexican tropical rain forests. Journal of Tropical Ecology 22:663-674.

Vázquez-Yanes, C. and A. Orozco-Segovia. 1993. Patterns of seed longevity and seed germination in the tropical rainforest. Annual Review of Ecology and Systematics 24:69-87.

Vieira, D. L. M. and A. Scariot. 2006. Principles of natural regeneration of tropical dry forests for restoration. Restoration Ecology 14:11-20.

Walker, L. R. and E. S. Chapin. 1987. Interactions among processes controlling successional change. Oikos 50:131135.

Walker, L. R., D. J. Zarin, N. Fetcher, R. W. Myster and A. H. Johnson. 1996. Ecosystem development and plant succession on landslides in the Caribbean. Biotropica 28:566-576.

Walker, L. R., J. Walker and R. J. Hobbs. 2007. Linking restoration and ecological succession. Springer Science, New York. 190 p.

Walker, L. R., D. A. Wardle, R. D. Bardgett and B. C. Clarkson. 2010. The use of chronosequences in studies of ecological succession and soil development. Journal of Ecology 98:725-736.

Wright, S. J. 2005. Tropical forest in a changing environment. Trends in Ecology and Evolution 20:553-560.

W3Tropicos. 2010. Missouri Botanical Garden's VAST nomenclatural database and associated authority files. http// tropicos.org; last access: 5.V.2010.

Appendix 1. Relative importance value (RIV) of the top ten plant species in each site 3 successional stages in a dry forest in Guerrero, Mexico. RD (relative density), RF (relative frequency), RC (relative cover).

\begin{tabular}{|c|c|c|c|c|c|c|c|c|c|}
\hline Species & $R D$ & $R F$ & $R C$ & $\begin{array}{l}\text { RIV } \\
(\%)\end{array}$ & Species & $R D$ & $R F$ & $R C$ & $\begin{array}{l}\text { RIV } \\
(\%)\end{array}$ \\
\hline ES1 & & & & & ES3 & & & & \\
\hline Gliricidia sepium & 0.27 & 0.08 & 0.27 & 21.10 & Gliricidia sepium & 0.24 & 0.07 & 0.24 & 18.58 \\
\hline Cordia sp. & 0.07 & 0.07 & 0.11 & 8.64 & Cordia sp. & 0.08 & 0.06 & 0.15 & 9.90 \\
\hline Havardia acatlensis & 0.08 & 0.07 & 0.09 & 8.05 & Cissus sp. & 0.12 & 0.06 & 0.11 & 9.83 \\
\hline Cissus sp. & 0.09 & 0.08 & 0.06 & 8.04 & Senna wislizeni & 0.06 & 0.05 & 0.06 & 6.14 \\
\hline Ipomoea pauciflora & 0.04 & 0.07 & 0.08 & 6.72 & Bursera longipes & 0.03 & 0.06 & 0.03 & 4.21 \\
\hline
\end{tabular}


Appendix 1. Continues.

\begin{tabular}{|c|c|c|c|c|c|c|c|c|c|}
\hline Species & $R D$ & $R F$ & $R C$ & $\begin{array}{l}\text { RIV } \\
(\%)\end{array}$ & Species & $R D$ & $R F$ & $R C$ & $\begin{array}{l}R I V \\
(\%)\end{array}$ \\
\hline Mimosa goldmanii & 0.08 & 0.07 & 0.04 & 6.52 & Acacia cochliacantha & 0.04 & 0.05 & 0.03 & 4.04 \\
\hline Senna wislizeni & 0.08 & 0.05 & 0.03 & 5.62 & Opuntia sp. & 0.05 & 0.04 & 0.01 & 3.75 \\
\hline Ceiba parvifolia & 0.02 & 0.04 & 0.09 & 5.19 & Ruprechtia fusca & 0.03 & 0.03 & 0.03 & 3.52 \\
\hline Acacia cochliacantha & 0.03 & 0.05 & 0.04 & 4.30 & Ceiba parvifolia & 0.01 & 0.04 & 0.03 & 3.22 \\
\hline $\begin{array}{l}\text { Alvaradoa amorphoides } \\
\text { ES2 }\end{array}$ & 0.02 & 0.05 & 0.02 & 3.58 & $\begin{array}{l}\text { Mimosa goldmanii } \\
\text { IS1 }\end{array}$ & 0.03 & 0.03 & 0.02 & 2.99 \\
\hline Cordia sp. & 0.15 & 0.07 & 0.26 & 16.33 & Lysiloma tergemina & 0.16 & 0.07 & 0.10 & 11.10 \\
\hline Cissus sp. & 0.12 & 0.07 & 0.11 & 10.31 & Bursera longipes & 0.08 & 0.05 & 0.11 & 8.44 \\
\hline Gliricidia sepium & 0.10 & 0.05 & 0.10 & 8.84 & Pterocarpus acapulcensis & 0.06 & 0.05 & 0.11 & 7.98 \\
\hline Havardia acatlensis & 0.05 & 0.04 & 0.06 & 5.49 & Bursera vejarvazquezii & 0.05 & 0.05 & 0.08 & 6.50 \\
\hline Mimosa goldmanii & 0.07 & 0.03 & 0.04 & 5.03 & Bursera aptera & 0.03 & 0.02 & 0.06 & 4.29 \\
\hline Ipomoea pauciflora & 0.03 & 0.04 & 0.05 & 4.46 & Euphorbia schlechtendalii & 0.04 & 0.05 & 0.03 & 4.21 \\
\hline Opuntia sp. & 0.06 & 0.06 & 0.01 & 4.43 & Mimosa polyantha & 0.04 & 0.05 & 0.02 & 3.98 \\
\hline Mimosa polyantha & 0.03 & 0.04 & 0.03 & 3.92 & Cissus sp. & 0.05 & 0.04 & 0.02 & 3.84 \\
\hline Senna wislizeni & 0.04 & 0.03 & 0.03 & 3.76 & Bursera morelensis & 0.02 & 0.04 & 0.03 & 3.67 \\
\hline $\begin{array}{l}\text { Alvaradoa amorphoides } \\
\text { IS2 }\end{array}$ & 0.04 & 0.04 & 0.02 & 3.50 & $\begin{array}{l}\text { Cordia sp. } \\
\text { MS1 }\end{array}$ & 0.02 & 0.03 & 0.04 & 3.61 \\
\hline Pterocarpus acapulcensis & 0.09 & 0.05 & 0.13 & 9.44 & Desmanthus balsensis & 0.13 & 0.05 & 0.12 & 10.17 \\
\hline Bursera longipes & 0.06 & 0.04 & 0.09 & 6.63 & Mimosa polyantha & 0.12 & 0.05 & 0.07 & 8.16 \\
\hline Cordia sp. & 0.07 & 0.03 & 0.08 & 6.31 & Bursera longipes & 0.06 & 0.05 & 0.07 & 6.80 \\
\hline Lysiloma tergemina & 0.07 & 0.04 & 0.06 & 6.29 & Bursera aptera & 0.07 & 0.04 & 0.06 & 6.01 \\
\hline Bursera morelensis & 0.04 & 0.04 & 0.07 & 5.72 & Mimosa goldmanii & 0.06 & 0.03 & 0.04 & 4.63 \\
\hline Bursera vejarvazquezii & 0.04 & 0.04 & 0.05 & 4.93 & Cordia sp. & 0.04 & 0.04 & 0.05 & 4.57 \\
\hline Acacia cochliacantha & 0.07 & 0.03 & 0.01 & 4.20 & Bursera morelensis & 0.04 & 0.04 & 0.03 & 4.09 \\
\hline Eysenhardtia polystachya & 0.04 & 0.03 & 0.04 & 4.17 & Bursera vejarvazquezii & 0.03 & 0.04 & 0.03 & 3.77 \\
\hline Bursera aptera & 0.03 & 0.04 & 0.03 & 4.10 & Bursera submoniliformis & 0.03 & 0.03 & 0.04 & 3.58 \\
\hline $\begin{array}{l}\text { Ziziphus mexicana } \\
\text { IS3 }\end{array}$ & 0.04 & 0.04 & 0.03 & 3.99 & $\begin{array}{l}\text { Bursera fagaroides } \\
\text { MS2 }\end{array}$ & 0.02 & 0.03 & 0.03 & 3.27 \\
\hline Bursera longipes & 0.11 & 0.06 & 0.11 & 9.52 & Bursera longipes & 0.09 & 0.06 & 0.12 & 9.40 \\
\hline Exostema caribaeum & 0.11 & 0.06 & 0.10 & 9.24 & Lysiloma tergemina & 0.12 & 0.05 & 0.09 & 9.10 \\
\hline Pterocarpus acapulcensis & 0.09 & 0.05 & 0.09 & 7.97 & Bursera vejarvazquezii & 0.06 & 0.05 & 0.12 & 8.30 \\
\hline Bursera morelensis & 0.07 & 0.06 & 0.08 & 7.21 & Exostema caribaeum & 0.06 & 0.04 & 0.08 & 6.41 \\
\hline Lysiloma tergemina & 0.07 & 0.05 & 0.05 & 5.99 & Pterocarpus acapulcensis & 0.05 & 0.04 & 0.06 & 5.33 \\
\hline Bursera vejarvazquezii & 0.04 & 0.05 & 0.07 & 5.83 & Bursera aptera & 0.05 & 0.04 & 0.05 & 4.97 \\
\hline Bursera submoniliformis & 0.04 & 0.04 & 0.08 & 5.78 & Euphorbia schlechtendalii & 0.05 & 0.04 & 0.04 & 4.81 \\
\hline Tecoma stans & 0.06 & 0.04 & 0.02 & 4.66 & Ceiba parvifolia & 0.04 & 0.04 & 0.05 & 4.38 \\
\hline Bursera aptera & 0.04 & 0.04 & 0.03 & 4.32 & Tecoma stans & 0.06 & 0.03 & 0.02 & 4.30 \\
\hline $\begin{array}{l}\text { Neobuxbaumia mezcalaensis } \\
\text { MS3 }\end{array}$ & 0.01 & 0.03 & 0.07 & 3.94 & Bursera morelensis & 0.03 & 0.05 & 0.04 & 4.29 \\
\hline Pseudosmodingium perniciosum & 0.11 & 0.04 & 0.15 & 10.56 & & & & & \\
\hline Acacia cochliacantha & 0.11 & 0.05 & 0.07 & 8.16 & & & & & \\
\hline Euphorbia schlechtendalii & 0.11 & 0.06 & 0.05 & 7.87 & & & & & \\
\hline Bursera morelensis & 0.04 & 0.05 & 0.10 & 6.57 & & & & & \\
\hline Lysiloma tergemina & 0.08 & 0.05 & 0.05 & 6.47 & & & & & \\
\hline Eysenhardtia polystachya & 0.07 & 0.05 & 0.05 & 5.95 & & & & & \\
\hline Bursera submoniliformis & 0.02 & 0.03 & 0.08 & 5.00 & & & & & \\
\hline Bursera aptera & 0.03 & 0.04 & 0.04 & 4.13 & & & & & \\
\hline Bursera longipes & 0.03 & 0.04 & 0.03 & 3.95 & & & & & \\
\hline Bursera vejarvazquezii & 0.02 & 0.05 & 0.02 & 3.63 & & & & & \\
\hline
\end{tabular}

